\title{
PENGARUH IMPLEMENTASI KEBIJAKAN E-GOVERNMENT TERHADAP KINERJA APARATUR KOTA CIMAHI
}

\author{
Dewi Kurniasih, Tatik Fidowaty, dan Poni Sukaesih
}

\author{
Program Studi Ilmu Pemerintahan Fakultas Ilmu Sosial dan Ilmu Politik \\ Universitas Komputer Indonesia \\ Email: dekur010575@yahoo.com
}

\begin{abstract}
ABSTRAK. Perkembangan teknologi, informasi dan komputer telah mempengaruhi penyelenggaraan pemerintahan di Indonesia. Pemerintah Kota Cimahi telah memanfaatkan teknologi komputer dalam upaya mewujudkan pemerintahan yang baik (good governance) melalui penerapan e-Government. Pelayanan yang baik berhubungan dengan kinerja aparatur, sehingga aparatur menjadi unsur penentu keberhasilan pemerintah dalam melayani masyarakat. Penelitian ini menggunakan desain penelitian kuantitatif dengan metode eksplanatori survey. Pengumpulan data dilakukan dengan cara pengamatan di lapangan, kuesioner, interview dan studi pustaka. Sedangkan ukuran sampel ditentukan berdasarkan probabilitas. Hasil penelitian menunjukkan bahwa implementasi kebijakan e-Government memberikan pengaruh sebesar 54,85\% terhadap kinerja aparatur pemerintah di Kota Cimahi, sedangkan sisanya sebesar $45,15 \%$ merupakan pengaruh faktor-faktor lain. Hal tersebut memberikan bukti empiris bahwa semakin baik implementasi kebijakan e-Government maka semakin meningkat kinerja aparatur pemerintah di Kota Cimahi. Komunikasi, sumber daya, disposisi/sikap pelaksana, serta struktur birokrasi telah memberikan kontribusi yang berarti terhadap keberhasilan kebijakan. Hal yang paling dominan dalam implementasi kebijakan ini adalah konsistensi sikap implementor sejak perencanaan sampai dengan pengawasan mulai tingkat pimpinan puncak sampai pelaksana untuk mengimplementasikan kebijakan sesuai dengan tujuan kebijakan.
\end{abstract}

Kata kunci: Implementasi kebijakan, e-Government, kinerja, aparatur

\section{THE INFLUENCE OF THE E-GOVERNMENT POLICY IMPLEMENTATION ON THE APPARATUS PERFORMANCE OF CIMAHI GOVERNMENT}

The development of computer, information, and technology has affected governance in Indonesia. Cimahi government has been utilizing computer technology in order to achieve good governance through the implementation of e-Government. Good service associated with the performance of the apparatus, so that the apparatus become a critical success element in serving the community. This study uses a quantitative research design with explanatory survey method. The data were collected by field observations, questionnaires, interviews and literature study. The sample size was determined based on probability. The results showed that the implementation of e-Government policies give as big as $54.85 \%$ influence of the government officials performance in Cimahi, while the remaining $45.15 \%$ is the influence of other factors. It provides empirical evidence that the better implementation of e-Government policy, the more increasing the performance of government officials in Cimahi. Communication, resources, disposition / executors' attitude, and the bureaucratic structure have given significant contribution to the success of the policy. The most dominant factor in the implementation of this policy is the consistence of the implementers in planning and monitoring from top-level manager to the executor so that the policy can be carried out in accordance with the policy objectives.

Keywords: Implementation of policy, e-government, performance, apparatus

\section{PENDAHULUAN}

Berkembangnya teknologi komunikasi dan komputer di era globalisasi, telah mempengaruhi penyelenggaraan pemerintahan di Indonesia.
Melalui pemanfaatan teknologi tersebut pemerintah mampu menciptakan pemerintahan yang lebih baik (good governance). Penerapan tata pemerintahan yang baik berimplikasi terhadap pelayanan publik yang lebih baik kepada 
masyarakat. Demi pencapaian cita-cita ideal tersebut, pemerintah perlu memperbaiki sistem birokrasi yang ada.

Instruksi Presiden (Inpres) No. 3 Tahun 2003 tentang Kebijakan dan Strategi Nasional Pengembangan e-Government telah mengintruksikan setiap Gubernur dan Bupati/ Walikota untuk mengambil langkah-langkah yang diperlukan sesuai dengan tugas, fungsi dan kewenangannya masing-masing guna terlaksananya pengembangan e-Government secara nasional termasuk di Kota Cimahi. Dalam rangka menghadapi perkembangan tersebut, Kota Cimahi perlu didukung oleh Sumber Daya Manusia (SDM) aparatur yang berkualitas. Kualitas sumber daya aparatur dan organisasi yang baik dalam pengembangan e-Government merupakan faktor yang sangatlah penting.

Penerapan e-Government pada pemerintahan saat ini belum berjalan mulus dibanding pihak swasta. Penggunaan sistem informasi masih belum maksimal. Masing-masing lembaga pemerintah baik pusat dan daerah belum memiliki hubungan kerjasama yang sinergis. Penerapan $e-$ Government di Kota Cimahi dapat menciptakan suatu hasil kerja yang efisien, partisipatif, berkeadilan, demokratis, transparan dan bertanggung jawab bila ditunjang dengan sistem aparatur negara yang modern, yang dilandasi oleh derajat rasionalitas yang tinggi. Pemerintah Kota Cimahi menyadari bahwa e-Government penting dalam reformasi birokrasi dewasa ini. Harapan yang muncul adalah penerapan e-Government akan memberikan pelayanan yang lebih baik kepada masyarakat. Namun, untuk penerapannya memang tidak mudah, karena memerlukan proses dan tahapan-tahapan seperti halnya meningkatkan hasil kerja birokrasi.

Penerapan e-Government di Kota Cimahi menghadapi beberapa tantangan. Salah satu diantaranya adalah masalah sumber daya aparatur yang belum memadai. Penerapan $e$ Government di Kota Cimahi perlu didukung oleh pegawai (aparat) yang mengerti mengenai sisi teknologi. Selain itu, diperlukan aparat yang mau belajar dan mampu menanggapi perubahan. Hal ini disebabkan teknologi informasi dan komunikasi berubah sedemikian cepat, sehingga kemauan belajar pun dituntut dari setiap aparatur.

Pemerintah Kota Cimahi berusaha meningkatkan kinerja aparaturnya dengan mendayagunakan teknologi informasi melalui suatu sistem manajemen informasi daerah yang terintegrasi, cepat dan tanggap. Hal ini diyakini, karena dengan kelancaran penyelenggaraan tugas pemerintahan dan pembangunan daerah di Kota Cimahi sangat tergantung pada kinerja pegawai. Aparatur merupakan unsur pemerintah yang langsung bertugas melayani masyarakat. Kinerja aparat yang baik dapat mendukung tugas pokok pengembangan sumber daya dan manajemen pegawai.

Pemerintah Kota Cimahi juga berusaha untuk mewujudkan suatu tatanan pemerintahan yang selalu tanggap terhadap perkembangan dan tuntutan aspirasi masyarakat dengan dukungan dari aparatur yang memiliki profesionalitas dan prestasi kerja berdasarkan pendidikan dan pelatihan yang memadai. Keberadaan aparatur yang berkualitas akan sangat ditentukan oleh kemampuan aparatur yang bersangkutan untuk mengimplementasikan prinsip-prinsip good governance dalam penyelenggaraan pemerintahan dan pelayanan publik mulai dari tingkat kota, kecamatan, sampai kelurahan.

\section{METODE}

Penelitian ini menjelaskan dan menganalisis tingkat keterpengaruhan variabel bebas dan variabel antara terhadap variabel terikat. Sehingga penelitian ini menggunakan desain penelitian kuantitatif dengan metode eksplanatori survey. Keterpengaruhan yang dimaksud adalah menjelaskan dan menganalisis besarnya pengaruh implementasi kebijakan e-government baik secara langsung, secara tidak langsung maupun secara bersama-sama terhadap kinerja aparatur.

Populasi dalam penelitian ini adalah aparatur yang berada di lingkungan Pemerintah Daerah Kota Cimahi yang secara keseluruhan berjumlah 5.863 orang. Untuk menentukan jumlah sampel maka menggunakan rumus Slovin sebagai berikut:

$$
n=\frac{N}{N d^{2}+1}
$$

$$
\begin{aligned}
\text { Dimana : } \mathrm{N} & =\text { Ukuran populasi } \\
\mathrm{d} & =\text { Batas kesalahan yang ditoleransi } \\
\mathrm{n} & =\text { Jumlah sampel } \\
1 & =\text { Angka Konstan }
\end{aligned}
$$

Berdasarkan data yang diperoleh, dengan jumlah populasi sebanyak 5.863 orang aparatur 
dengan tingkat kekeliruan yang digunakan adalah $5 \%$, maka jumlah sampel yang diteliti adalah:

$$
\begin{aligned}
\mathrm{n} & =\frac{6038}{6038 \times(0.05)^{2}+1} \\
\mathrm{n} & =375,15 \text { atau } 376
\end{aligned}
$$

sehingga jumlah sampel minimum sebesar 376 orang.

Dalam pengumpulan data dikembangkan instrumen penelitian berupa kuesioner, wawancara, format observasi dan daftar isian. Kuesioner berisikan pertanyaan-pertanyaan untuk menjaring informasi/data yang diperlukan dalam penelitian yang ditujukan kepada responden yang terkait dalam penelitian ini.

Wawancara dilakukan kepada beberapa pejabat pemerintah, masyarakat terkait, tokoh masyarakat dan lain-lain yang dapat mendukung data penelitian ini. Wawancara ini dilakukan untuk melengkapi data yang tidak dapat dijaring melalui instrumen penelitian lainnya. Format observasi dikembangkan untuk menjaring data setiap aktifitas yang dianggap penting dan terkait dalam penelitian ini.
Uji validitas dan realibilitas atas instrumen penelitian ini telah dilakukan. Uji validitas mengggunakan metode cosntruct validity, yang mengkorelasikan skor setiap butir pernyataan dengan jumlah skor butir pernyataan lainnya dalam satu konsep pengukuran. Sedangkan uji reliabilitas menggunakan metode internal konsistensi, dengan melihat kekonsistenan jawaban responden dari setiap butir pernyataan melalui variasi skor jawaban responden. Butir pernyataan dikatakan valid, jika memiliki koefisien korelasi $\geq 0,30$ dan sekumpulan butir pernyataan dinyatakan reliabel jika memiliki koefisien reliabilitas $\geq 0,70$ (Barker et al, 2002:72).

\section{HASIL PENELITIAN DAN PEMBAHASAN}

\section{Implementasi Kebijakan e-Government}

Penerapan kebijakan e-Government di Kota Cimahi terungkap melalui jawaban responden terhadap pernyataan-pernyataan yang ada pada kuesioner yang terdiri dari 4 dimensi, 12 indikator dan dioperasionalisasikan menjadi 18 butir pernyataan. Berdasarkan data yang telah terkumpul diperoleh gambaran penerapan kebijakan e-Government di Kota Cimahi sebagai berikut:

Tabel 1. Rekapitulasi Rata-Rata Skor Tanggapan Responden Pada Variabel Implementasi Kebijakan e-Government

\begin{tabular}{clcc}
\hline No & \multicolumn{1}{c}{ Indikator } & $\begin{array}{c}\text { Mean } \\
\text { Skor }\end{array}$ & Kriteria \\
\hline 1 & Transformasi & 3,66 & Cukup \\
2 & Kejelasan & 3,77 & Cukup \\
3 & Konsistensi & 3,76 & Cukup \\
& Dimensi Komunikasi & $\mathbf{3 , 7 3}$ & Cukup \\
\hline 4 & Sumber daya manusia & 3,73 & Cukup \\
5 & Sumber daya anggaran & 3,74 & Cukup \\
6 & Sumber daya peralatan & 3,77 & Cukup \\
7 & Sumber daya informasi dan kewenangan & 3,77 & Cukup \\
& Dimensi Sumber Daya & $\mathbf{3 , 7 5}$ & Cukup \\
\hline 8 & Komitmen & 3,83 & Cukup \\
9 & Pengetahuan & 3,77 & Cukup \\
10 & Pemahaman & 3,76 & Cukup \\
& Dimensi Disposisi & $\mathbf{3 , 7 9}$ & Cukup \\
\hline 11 & Standar operasional prosedur & 3,81 & Cukup \\
12 & Fragmentasi & 3,78 & Cukup \\
& Dimensi Struktur Birokrasi & $\mathbf{3 , 7 9}$ & Cukup \\
\hline & & $\mathbf{3 , 7 6}$ & Cukup \\
\hline
\end{tabular}

Sumber: Hasil penelitian tahun 2012 (diolah) 
Apabila kita lihat grand mean skor tanggapan responden mengenai implementasi kebijakan $e$ Government di Kota Cimahi sebesar 3,76 yang berada di antara interval $3-4$. Dengan demikian dapat disimpulkan bahwa implementasi kebijakan e-Government di Kota Cimahi sudah cukup baik. Demikian juga bila dilihat berdasarkan dimensinya, tampak bahwa rata-rata skor tanggapan responden terhadap keempat dimensi implementasi kebijakan e-Government di Kota Cimahi termasuk dalam kategori cukup.

Dimensi komunikasi menunjukkan banyaknya responden yang menilai keterbukaan dalam penyampaian informasi pada pelaksanaan $e$ Government di Kota Cimahi sudah cukup tinggi, bahkan banyak juga responden yang berpendapat keterbukaan dalam penyampaian informasi pada pelaksanaan e-Government di Kota Cimahi sudah tinggi, demikian juga mengenai tujuan/sasaran kebijakan e-Government di Kota Cimahi sudah jelas menurut sebagian besar responden. Hal ini terlihat dari komunikasi dua arah yang sudah terjain dengan cukup baik diantara aparatur di berbagai SKPD yang ada di Kota Cimahi

Pada dimensi sumberdaya, Sumber Daya Aparatur pelaksana e-Government di Kota Cimahi sudah mencukupi. Terlihat dari tingkat pendidikan responden yang minimal D3 dan paling tinggi S3, rata-rata pendidikan aparatur S1 sehingga dalam pelaksanaan e-government di kota Cimahi jumlah aparatur sudah cukup dan cakap serta sudah ada deskripsi tugas yang jelas di sesuaikan dengan keahlian masing-masing aparatur. Sumber daya anggaran sudah mencukupi dalam pelaksanaan $e$ Government di Kota Cimahi di sertai dengan pertanggungjawaban anggaran dalam pelaksanaan e-Government di Kota Cimahi juga sudah cukup memadai terlihat dari pengeluaran yang sudah sesuai dengan kebutuhan dalam pelaksaan e-Government di kota Cimahi. Sarana dan prasarana dalam pelaksanaan e-Government di Kota Cimahi sudah cukup layak, demikian juga dengan informasi dalam pelaksanaan $e$ Government di Kota Cimahi sudah cukup memadai dan cukup jelas. Demikian juga dengan kejelasan kewenangan dalam pelaksanaan $e$ Government di Kota Cimahi sudah cukup jelas. Hal ini terlihat dari pembagian tugas yang jelas antar aparatus di sesuaikan dengan jabatan masing-masing aparatur.
Terkait dimensi disposisi terlihat komitmen dari aparat untuk melaksanakan tujuan dan sasaran pelaksanaan kebijakan e-Government di Kota Cimahi cukup tinggi yang didukung dengan kejujuran dari aparat untuk melaksanakan tujuan dan sasaran pelaksanaan kebijakan e-Government di Kota Cimahi. Demokratisasi dari aparat untuk melaksanakan tujuan dan sasaran pelaksanaan kebijakan e-Government di Kota Cimahi juga sudah cukup tinggi karena setiap aparatur bebas untuk mengemukakan ide/gagasn dan pendapat yang membangun dalam pelaksanaan eGovernment di kota Cimahi.

Sedangkan pada dimensi struktur birokrasi, SOP sudah tersedia dan fragmentasi (penyebaran tanggung jawab) dalam pelaksanaan $e$ Government sudah cukup tinggi. Berdasarkan hasil pengamatan dan penelitian SOP Kota Cimahi memiliki manfaat sebagai standarisasi yang wajib dilakukan dalam menyelesaikan pekerjaan, mengurangi kesalahan dan kelalaian. SOP menjamin proses yang telah ditetapkan dan dijadwalkan dapat berlangsung sebagaimana seharusnya. Selain itu, SOP akan menjamin tersedianya data untuk penyempurnaan proses sehingga akuntabilitas dengan melaporkan dan mendokumentasikan hasil dalam pelaksanaan tugas meningkat. Efisiensi dan efektivitas pelaksanaan tugas juga akan meningkat karena SOP memberikan cara konkrit untuk perbaikan kinerja dan menghindarikan diri dari terjadinya variasi proses pelaksanaan kegiatan dan tumpang tindih pelaksanaan tugas. Dengan demikian SOP membantu pejabat administrasi pemerintahan yang terlibat dalam proses pelayanan menjadi lebih mandiri sehingga informasi yang diperlukan dalam penyusunan standar dan memberikan informasi kinerja tersedia secara memadai.

\section{Kinerja Aparatur}

Kinerja aparatur pemerintah Kota Cimahi terungkap melalui jawaban responden terhadap pernyataan-pernyataan yang ada pada kuesioner yang terdiri dari 6 dimensi, 16 indikator dan diperasionalisasikan menjadi 19 butir pernyataan. Berdasarkan data yang telah terkumpul diperoleh gambaran kinerja aparatur pemerintah Kota Cimahi sebagai berikut: 
Tabel 2. Rekapitulasi Rata-Rata Skor Tanggapan Responden Pada Variabel Komitmen Kinerja Aparatur

\begin{tabular}{clcc}
\hline No & \multicolumn{1}{c}{ Indikator } & $\begin{array}{c}\text { Mean } \\
\text { Skor }\end{array}$ & Kriteria \\
\hline 1 & Tujuan & 3,76 & Cukup \\
2 & Proses & 3,68 & Cukup \\
3 & Hasil & 3,78 & Cukup \\
& Dimensi Kualitas & $\mathbf{3 , 7 4}$ & Cukup \\
\hline 4 & Beban kerja & 3,74 & Cukup \\
5 & Besaran hasil & 3,67 & Cukup \\
& Dimensi Kuantitas & $\mathbf{3 , 7 1}$ & Cukup \\
\hline 6 & Waktu penyelesaian tugas & 3,79 & Cukup \\
7 & Kehadiran & 3,74 & Cukup \\
& Dimensi Ketepatan Waktu & $\mathbf{3 , 7 7}$ & Cukup \\
\hline 8 & Kebutuhan SDM & 3,82 & Cukup \\
9 & Penggunaan dana & 3,78 & Cukup \\
10 & Pemanfaatan teknologi & 3,76 & Cukup \\
11 & Pemberdayaan sarana dan prasarana & 3,80 & Cukup \\
& Dimensi Efektifitas Biaya & $\mathbf{3 , 7 9}$ & Cukup \\
\hline 12 & Sikap aparatur & 3,86 & Cukup \\
13 & Banyaknya kesalahan & 3,82 & Cukup \\
& Dimensi Kebutuhan Pengawasan & $\mathbf{3 , 8 4}$ & Cukup \\
\hline 14 & Kepercayaan diri & 3,93 & Cukup \\
15 & Ketulusan & 3,85 & Cukup \\
16 & Kerjasama & 3,93 & Cukup \\
& Dimensi Pengaruh Interpersonal & $\mathbf{3 , 9 0}$ & Cukup \\
\hline
\end{tabular}

Sumber: Hasil penelitian tahun 2012 (diolah)

Tabel di atas dapat menunjukkan grand mean skor tanggapan responden mengenai kinerja aparatur pemerintah Kota Cimahi sebesar 3,79 berada di antara interval $3-4$. Dengan demikian dapat simpulkan bahwa kinerja aparatur pemerintah Kota Cimahi cukup tinggi. Demikian juga bila dilihat berdasarkan dimensi, tampak bahwa rata-rata skor tanggapan responden terhadap keenam dimensi kinerja aparatur pemerintah Kota Cimahi termasuk dalam kategori cukup. Kinerja sering digunakan untuk menyebut prestasi atau tingkat keberhasilan individu atau kelompok. Kinerja bisa diketahui jika individu atau kelompok mempunyai kriteria keberhasilan yang telah ditetapkan.

Tingkat pencapaian mengenai kinerja aparatur dapat dilihat dari hasil kerja aparatur Kota Cimahi itu sendiri. Indikator-indikator dalam penelitian mengenai kinerja aparatur di Kota Cimahi terdiri kualitas, kuantitas, ketepatan waktu, efektivitas biaya, kebutuhan pengawasan, dan pengaruh interpersonal.
Pada Dimensi kualitas, aparatur Kota Cimahi cukup tinggi, hal ini terlihat dari kesesuaian antara kegiatan dan tujuan yang ditetapkan dalam pelaksanaan e-government di Kota Cimahi. Berdasarkan hasil pengamatan, dalam rangka implementasi kebijakan e-government di Kota Cimahi, kegiatan-kegiatan yang dilakukan aparatur dalam rangka pencapaian tujuan sudah ditentukan dalam sebuah rencana kerja dan rencana strategis. Di Kota Cimahi tujuan ditetapkan dalam Peraturan Daerah Kota Cimahi Nomor 11 Tahun 2003 tentang Rencana Strategis Daerah Kota Cimahi dimana tujuan inilah yang menjadi patokan aparatur dalam bekerja.

Kualitas dari pemerintah Kota Cimahi tidak mungkin meningkat tanpa adanya usaha-usaha yang nyata untuk meningkatkannya. Oleh karena itu perlu adanya kesesuaian kegiatan-kegiatan, proses dan hasil kerja dengan tujuan yang telah ditetapkan dalam pelaksanaan e-government. 
Pada dimensi kuantitas kerja, menunjukkan cukup tinggi, hal ini dapat dilihat dari beban kerja dan besaran hasil. Kesesuaian antara jumlah beban kerja dengan tujuan yang sudah ditetapkan dalam pelaksanaan ee-government di Kota Cimahi menunjukkan cukup tinggi. Berdasarkan hasil pengamatan, di Kota Cimahi setiap aparatur sudah mempunyai job description-nya masingmasing, dan apabila dilihat, beban kerja yang dipangku oleh setiap aparatur dalam rangka implementasi kebijakan e-government sudah cukup sesuai dengan tujuan yang telah ditargetkan.

Pada dimensi ketepatan waktu, terlihat bahwa aparatur dalam mengimplementasikan kebijakan e-government ini cukup tinggi. Hal ini terlihat dari ketepatan waktu penyelesaian tugas pada setiap aparatur dalam pelaksanaan $e$ government di Kota Cimahi cukup tepat waktu. Berdasarkan pengamatan, aturan yang berlaku di lingkungan Pemerintah Kota Cimahi dalam menentukan waktu merupakan langkah pemerintah untuk memberikan peringatan kepada aparatur dalam menjalankan tugasnya. Maksud dari peringatan tersebut bertujuan agar aparatur dalam mengimplementasikan e-government tidak menyimpang dari ketentuan waktu yang telah ditentukan.

Berdasarkan hasil dari penelitian Aparatur Pemerintah Kota Cimahi dalam implementasi $e$ Government terutama dalam memberikan pelayanan durasi minimalnya waktu yang diberikan dan ditentukan dalam SOP adalah waktu proses Lima (5) hari kerja. Dibutuhkan suatu aplikasi yang baik yang dapat memberikan pelayanan cepat, tepat dan akurat dalam menunjang proses pelayanan yang cepat. Sebelum menggunakan fasilitas elektronik, aparatur Pemerintah Kota Cimahi masih menggunakan sistem manual khususnya dalam proses pencarian data pemohon yaitu dengan menggunakan komputer, tetapi berkas-berkasnya secara fisik disimpan. Setelah adanya aplikasi ini data pemohon dapat lebih cepat ditemukan. Setelahmemanfaatkan barcode Kota Cimahi dalam pelayanan mengalami perubahan yang cukup baik. Waktu yang diperlukan hanya lima menit dalam pencarian berkas.

Pada Dimensi efektivitas biaya, terlihat cukup efektif. Efektivitas biaya dalam implementasi kebijakan e-government ini terlihat dari kebutuhan SDM, penggunaan dana, pemanfaatan teknologi, pemberdayaan sarana dan prasarana.

Ketersediaan kebutuhan SDM pada setiap unit kerja dalam pelaksanaan e-government cukup memadai, ini terlihat dari hasil pengamatan bahwa jumlah aparatur di setiap SKPD dapat menunjang terimplementasinya e-government ini. Jumlah aparatur pada Pemerintah Kota cimahi sebanyak 5.913 aparat. Jumlah tersebut berasal dari 42 instansi yang ada di Kota Cimahi.

Ketersediaan dana pada setiap kegiatan dalam pelaksanaan e-government pada dasarnya cukup memadai, hal ini terlihat dari alokasi dana yang dianggarkan di setiap tahun anggaran selalu sesuai dengan kebutuhan. Ketersediaan teknologi dalam pelaksanaan e-government di Kota Cimahi cukup memadai ini terlihat dari berbagai teknologi yang digunakan di Kota Cimahi seperti Hub Switch 1 dan 2, Kabel UTP, Konektor, Lancard, UPS, Rack Panel, LanCard Serat Optik, Komputer Server.

Optimalisasi pemanfaatan teknologi dalam pelaksanaan e-government di Kota Cimahi sudah cukup optimal, artinya bahwa aparatur dalam rangka mengimplementasikan kebijakan $e$ government sudah memanfaatkan teknologi yang tersedia di Kota Cimahi. Pemanfaatan teknologi ini berhubungan dengan kemampuan atau keterampilan (skill) yang merupakan kemampuan yang diperoleh melalui pendidikan dan pelatihanpelatihan.

Berdasarkan dari hasil penelitian dilapangan, sarana dan prasarana yang ada di Kota Cimahi khususnya dalam pelaksanaan e-government sudah cukup lengkap dan memadai sesuai dengan kebutuhannya, hal ini terlihat dari ketersediaan sarana prasarana di setiap SKPD, misalnya Peralatan komputer memiliki teknologi yang canggih sesuai perkembangan yang ada, fasilitas gedung yang memadai, lingkungan yang bersih dan rapih, serta infrastruktur yang cukup baik, sehingga aparatur Kota Cimahi dalam melaksanakan tugas pokok dan fungsinya dapat berjalan dengan lancar.

Pada dimensi kebutuhan pengawasan, terlihat dari sikap aparatur dan banyaknya kesalahan dalam bekerja yang menunjukkan cukup. Kemandirian aparatur dalam pelaksanaan e-government cukup tinggi, dikarenakan berdasarkan hasil pengamatan aparatur di Kota Cimahi cukup mampu dalam hal pengawasan pelaksanaan e-government di Kota Cimahi, 
pimpinan cukup tinggi mengawasi aparatur untuk menghindari terjadinya banyak kesalahan.

Pada Dimensi pengaruh interpersonal dalam pelaksanaan e-government menunjukkan cukup tinggi. Pengaruh interpersonal ini dapat ditinjau dari kepercayaan diri, ketulusan, dan kerjasama. Kepercayaan diri aparatur dalam melaksanakan e-government di Kota Cimahi terlihat cukup tinggi, hal ini terbukti dari ketulusan aparatur dalam menunaikan pekerjaan e-government di Kota Cimahi cukup tinggi, dimana aparatur benar-benar bekerja untuk melayani kepentingan masyarakat.

Demikian halnya dengan kerjasama antar aparatur dalam pekerjaan e-government di Kota Cimahi cukup tinggi. Kerjasama aparatur di Kota Cimahi dilakukan dengan perusahaan atau stakeholder yang merupakan kemampuan aparatur Kota Cimahi dalam melakukan kerjasama antara pihak-pihak yang terkait dalam pelaksanaan e-government. Kerjasama tersebut dilakukan untuk meningkatkan partisipasi para pelaku pembangunan, kemitraan, dan pemberdayaan masyarakat dalam pembangunan perkotaan. Peningkatan partisipasi tersebut didukung dengan kerjasama Pemda dengan Forum LITMAS (Forum gabungan ITB, Unikom, Unwim dan Universitas Jenderal Ahmad Yani dalam rangka pengembangan masyarakat).

\section{Pengujian Hipotesis}

Sesuai tujuan penelitian, yaitu untuk menguji pengaruh implementasi kebijakan e-Government $(\xi)$ terhadap kinerja aparatur pemerintah $(\eta)$ maka penulis telah melakukan analisis kuantitatif menggunakan structural equation modeling. Dalam structural equation modeling ada dua jenis model yang terbentuk, yaitu model pengukuran dan model struktural.

Model struktural adalah model yang menghubungkan variabel laten exogenous dengan variabel laten endogenous atau hubungan variabel endogenous dengan variabel endogenous lainnya. Berikut rangkuman nilai-nilai yang digunakan dalam model struktural.

Tabel 3. Rangkuman Hasil Uji Statistik

\begin{tabular}{cccc}
\hline Jalur & Koefisien & $\mathbf{t}_{\text {hitung }}{ }^{*}$ & R-Square \\
\hline$\xi \rightarrow \eta$ & 0,7406 & 14,2042 & 0,5485 \\
\hline$* t_{\text {kritis }}=1,96$ & & & \\
Sumber: Hasil penelitian tahun 2012 (diolah SPSS)
\end{tabular}

Implementasi kebijakan e-Government memberikan pengaruh sebesar $54,85 \%$ terhadap kinerja aparatur pemerintah di Kota Cimahi, sedangkan sisanya sebesar $45,15 \%$ merupakan pengaruh faktor-faktor lain yang tidak diteliti seperti kesipan masyarakat dalam penerapan $e$ Government karena tingkat pendidikan masyarakat yang minim. Selanjutnya dilakukan pengujian hipotesis untuk membuktikan ada tidaknya pengaruh implementasi kebijakan $e$ Government terhadap kinerja aparatur pemerintah di Kota Cimahi.

Dari hasil pengolahan data menggunakan software LISREL diperoleh persamaan struktural sebagai berikut.

Tabel 4. Persamaan struktural pengaruh implementasi kebijakan e-Government terhadap kinerja aparatur pemerintah

\begin{tabular}{ccc}
\hline $\begin{array}{c}\text { Endegenous } \\
\text { Constructs }\end{array}$ & \multicolumn{1}{c}{ Exogenous Constructs } & \multirow{2}{*}{ R-square } \\
\hline$\eta_{\mathbf{1}}$ & 0,7406 & 0,5485 \\
& $(14,2042)$ & \\
\hline \multicolumn{2}{l}{ Keterangan: Angka dalam kurung adalah nilai statistik uji-t. } \\
Sumber: Hasil penelitian tahun 2012 (diolah SPSS)
\end{tabular}

Setelah koefisien jalur dihitung, selanjutnya untuk membuktikan apakah implementasi kebijakan e-Government berpengaruh signifikan terhadap kinerja aparatur pemerintah, maka dilakukan pengujian dengan rumusan hipotesis statistik sebagai berikut: 


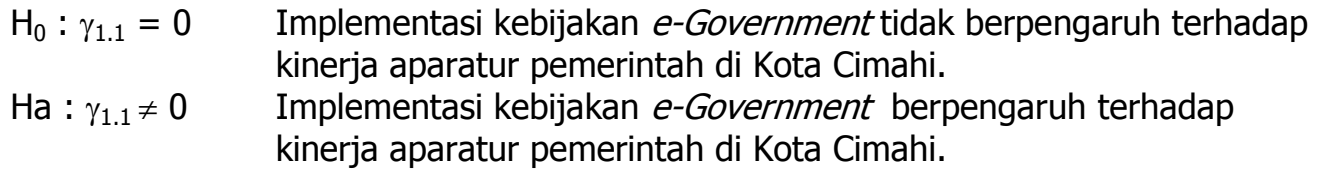

Tabel 5. Hasil Pengujian Pengaruh Implementasi Kebijakan e-Government Terhadap Kinerja Aparatur Pemerintah

\begin{tabular}{ccccc}
\hline Koef. Jalur & $\mathbf{t}_{\text {hitung }}$ & $\mathbf{t}_{\text {kritis }}$ & Ho & Ha \\
\hline 0,7406 & 14,2042 & 1,96 & ditolak & Diterima \\
\hline Sumber: Hasil penelitian tahun 2012 (diolah SPSS) &
\end{tabular}

Berdasarkan hasil pengujian dapat dilihat

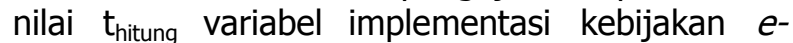
Government $(14,2042)$ lebih besar dari $t_{\text {kritis }}$ $(1,96)$. Karena nilai $t_{\text {hitung }}$ lebih besar dibanding $t_{\text {kritis }}$ maka pada tingkat kekeliruan $5 \%$ diputuskan untuk menolak Ho sehingga $\mathrm{Ha}$ diterima. Jadi berdasarkan hasil pengujian dapat disimpulkan bahwa implementasi kebijakan $e$ Government berpengaruh terhadap kinerja aparatur pemerintah di Kota Cimahi. Hasil penelitian ini memberikan bukti empiris bahwa semakin baik implementasi kebijakan eGovernment akan meningkatkan kinerja aparatur pemerintah di Kota Cimahi.

\section{SIMPULAN}

Berdasarkan pembahasan di atas, dapat disimpulkan bahwa Bobot faktor menunjukkan bahwa konsistensi pelaksanaan e-Government, kecakapan Sumber Daya Aparatur, kecukupan Sumber Daya Aparatur, kejelasan informasi, kejelasan kewenangan, demokratisasi dari aparat untuk melaksanakan tujuan dan sasaran serta fragmentasi (penyebaran tanggung jawab) paling menentukan dalam implementasi kebijakan $e$ Government di Kota Cimahi.

Melalui bobot faktor juga menunjukkan bahwa kesesuaian antara proses dan tujuan, ketersediaan kebutuhan SDM pada setiap unit kerja, kesesuaian penggunaan dana dengan tujuan, ketersediaan teknologi, optimalisasi pemanfaatanteknologi, optimalisasi pemberdayaan sarana dan prasarana, kemandirian aparatur serta kepercayaan diri aparatur dalam menunaikan pekerjaan menjadi faktor paling menentukan dalam kinerja aparatur pemerintah di Kota Cimahi.

Implementasi kebijakan e-Government terbukti berpengaruh signifikan terhadap kinerja aparatur pemerintah di Kota Cimahi. Implementasi kebijakan e-Government memberikan pengaruh sebesar $54,85 \%$ terhadap perubahan kinerja aparatur pemerintah di Kota Cimahi. Meskipun tidak terlalu besar, namun implementasi kebijakan e-Government merupakan salah satu faktor yang dominan dalam menentukan perubahan kinerja aparatur pemerintah di Kota Cimahi.

Guna mengamati proses sosial yang terjadi di masyarakat diperlukan kajian terus menerus mengenai komunikasi pemerintahan, agar pelayanan publik dapat dilaksanakan secara optimal.

Perkembangan teknologi kepemerintahan saat ini memerlukan kajian yang lebih mendalam mengenai e-Government dan pola-pola aplikasinya.

Pemerintah Kota Cimahi perlu meningkatkan sosialisasi, koordinasi dan komunikasi kepada masyarakat mengenai penerapan e-Government.

Perlunya meningkatkan pelayanan perizinan kepada masyarakat melalui pengadaan infrastruktur seperti jaringan komputerisasi (LAN) yang menghubungkan antar SOPD di Kota Cimahi secara nirkabel atau internet.

Diperlukan pengembangan data base baik melalui website maupun Sistem Informasi Manajemen kedepan secara on line yang dapat menunjang interaksi antarpemerintahan, swasta dan masyarakat, sehingga proses perijinan dapat dilaksanakan lebih akurat.

Tingkatkan kualitas pengelola data dengan pelatihan dan pembinaan apartur secara terus menerus sehingga pelaksanaan e-Government menjadi lebih baik lagi. 
Perlunya penambahan komputer dan jaringan internet yang memadai sebagai penunjang kerja penerapan e-Government di Kota Cimahi.

\section{DAFTAR PUSTAKA Buku-Buku}

Anwar, M. Khoirul dan Asianti Oetojo S. 2004. Aplikasi Sistem Informasi Manajemen Bagi Pemerintahan di Era Otonomi Daerah SIMDA. Yogayakarta: Pustaka Pelajar.

Bernardin, H. John and Joyce EA Russel. 1998. Human Resource Management: An Experiental Approach. Boston: McGraw-Hill.

Cooper, D. R, \& Schindler, P. S. 2006. Business Research Methods.(9 ${ }^{\text {th }}$ ed.). International edition. Mc Graw Hill

Hidayat, Sucherly. 1986. Peningkatan Produktivitas Organisasi Pemerintah dan Pegawai Negeri, Kasus Indonesia dalam journal Prisma No.12, Jakarta LP3ES.

Holmes, Douglas. 2001. E-Gov, E-Business Strategies fot Government. London:Nicholas Brealey Publishing.

Indrajit, Richardus Eko. 2006. Electronic Government: Strategi Pembangunan dan Pengembangan Sistem Pelayanan Publik Berbasis Teknologi Digital. Yogyakarta:Andi.

dkk. 2005. E-Government in Action Ragam Kasus Implementasi Sukses di Berbagai Belahan Dunia. Yogyakarta:Andi.

Kaho, Josef Riwu. 2001. Prospek Otonomi Daerah di Negara Republik Indonesia dan Identifikasi Beberapa Faktor Yang Mempengaruhi Penyelenggaraannya. Jakarta:Rajawali Pers.

Mangkunegara, Anwar Prabu. 2007. Evaluasi Kinerja SDM. Bandung:Refika Aditama.

Nurcholis, Hanif. 2005. Teori dan Praktik Pemerintah dan Otonomi Daerah. Jakarta:PT. Grasindo.
Sarwono, Jonathan. 2005. SPSS Teori dan Aplikasi Menggunakan SPSS versi 12 Edisi II. Bandung:Danamartha Sejahtera Utama.

Sedarmayanti. 2004. Good Governance, Membangun Sistem Manajemen Kinerja Guna Meningkatkan Produktivitas Menuju Good Governance. Bandung:Mandar Maju.

Simanjuntak, J. Payaman. 2005. Manajemen dan Evaluasi Kinerja. Jakarta:LP. FEUI.

Sugiyono. 2002. Metode Penelitian Administratif. Bandung:Alfabeta

Suliyanto. 2006. Metode Riset Bisnis. Yogyakarta:ANDI

Surjadi. 2009. Pengembangan Kinerja Pelayanan Publik. Bandung:Refika Aditama.

Tangkilisan, Hessel Nogi S. 2005. Kebijakan dan Manajemen Otonomi Daerah. Yogyakarta:Lukman Offset.

Wahab, Solihin Abdul. 2003. Analisis Kebijakan dari Formulasi ke Implementasi Kebijakan Negara. Jakarta : PT Bumi Aksara

Weiner, Myron. 1994. Modernisasi dan Dinamika Pertumbuhan. Yogyakarta:Gadjahmada University Press.

Widodo, Joko. 2001. Good Governance. Telaah dari Dimensi: Akuntabilitas dan Kontrol Birokrasi Pada Era Desentralisasi dan Otonomi Daerah. Surabaya:Insan Cendikia.

2006. Membangun Birokrasi Berbasis Kinerja. Malang:Bayumedia.

Yudoyono, Bambang. 2001. Otonomi Daerah, Desentralisasi dan Pengembangan Sumber Daya Manusia Aparatur Pemerintah Daerah dan DPRD. Jakarta:Pustaka Sinar Harapan.

\section{Perundang-Undangan}

Intruksi Presiden No.3 Tahun 2003 tentang Panduan Kebijakan Strategi Nasional Elektronik Government.

Undang-Undang Nomor 43 Tahun 1999 tentang Pokok-Pokok Kepegawaian. 